\title{
Juvenile nephropathic cystinosis
}

INSERM

\section{Source}

INSERM. (1999). Orphanet: an online rare disease and orphan drug data base. Juvenile nephropathic cystinosis. ORPHA:411634

Nephropathic juvenile cystinosis is the intermediate form, in regards to severity and age of onset, of cystinosis (see this term), a metabolic disease characterized by an accumulation of cystine inside the lysosomes that causes damage in different organs and tissues, particularly in the kidneys and eyes. 